\title{
TANGGUNG JAWAB NEGARA ATAS HAK PENDIDIKAN BAGI ANAK BERKEBUTUHAN KHUSUS
}

\author{
A'an Efendi', Dwi Nurhayati Adhani' \\ Bagian Hukum Tata Negara ${ }^{1}$ \\ Fakultas Hukum Universitas Jember \\ Program Studi Pendidikan Anak Usia Dini ${ }^{2}$ \\ Fakultas Ilmu Pendidikan \\ Universitas Trunojoyo Madura \\ Email: efendihukum@gmail.com, adhaniuwi@gmail.com
}

\begin{abstract}
ABSTRAK
Hak atas pendidikan bagi anak berkebutuhan khusus dapat dilihat dari dua sisi. Bagi anak berkebutuhan khusus sebagai pemegang hak ia tidak hanya dapat berharap hak itu diperolehnya tetapi dapat menuntut pelaksanaanya. Dari aspek negara, negara terikat kewajiban hukum untuk menghormati dan melaksanakan hak itu. Kegagalan melaksanakan kewajiban hukum yang berakibat timbulnya kerugian bagi pemegang hak menyebabkan negara dapat dibebani tanggung jawab hukum untuk memberikan ganti kerugian. Hak atas pendidikan bagi anak berkebutuhan khusus adalah hak konstitusional yang dijamin konstitusi yang selanjutnya harus diatur penjabarannya lebih lanjut dalam peraturan perundang-undangan di bawah konstitusi. Pengaturan hak dalam aturan-aturan hukum yang mengikat itu harus ditindaklanjuti dengan tindakan pelaksanaan hak supaya tidak sekadar menjadi hak di atas kertas.
\end{abstract}

Kata Kunci: Tanggung Jawab Negara, Hak atas Pendidikan, Anak Berkebutuhan Khusus

\begin{abstract}
The right to education for children with special needs can be seen from two sides. For children with special needs as rights holders, they can not only hope that the rights are obtained, but can demand their implementation. From the aspect of the state, the state is bound by a legal obligation to respect and implement that right. Failure to carry out legal obligations that result in loss to the right holders causes the state to be liable for legal liability to compensate. The right to education for children with special needs is a constitutional right guaranteed by the constitution which furthermore must be regulated further in the legislation under the constitution. The regulation of rights in binding legal rules must be followed up with the act of exercising rights so that they are not merely rights on paper.
\end{abstract}

Keywords: State Responsibility, Right to Education, Children with Special Needs

\section{PENDAHULUAN}

$\begin{array}{ll}\text { Hans Kelsen salah satu } \\ \text { eksponen } & \text { terkemuka paham }\end{array}$ positivisme hukum mengemukakan bahwa dalam penataan hierarki dari tatanan hukum suatu negara konstitusi merupakan yang tertinggi dalam hukum nasional (Kelsen, 1949:124). Konstitusi adalah tingkat tertinggi dari hukum positif (Kelsen, 1992:64) yaitu hukum yang ditetapkan oleh negara (Altman, TT:32). Konstitusi di sini tidak hanya bermakna formal tetapi juga material. Konstitusi dalam arti formal adalah dokumen yang khidmat, seperangkat norma hukum yang hanya dapat diubah di bawah 
peninjauan preskipsi khusus, tujuannya adalah untuk membuat perubahan konstitusi ini lebih sulit. Konstitusi dalam pengertian material terdiri atas aturan-aturan yang mengatur pembentukan norma hukum umum, khususnya pembuatan peraturan perundang-undangan (Kelsen, 2005: 222).

Pada saat ini hampir setiap negara di dunia memiliki konstitusi tertulis yang merupakan hukum tertinggi negara (Turpin and Tomkins, 2007:3). Tiga negara tanpa konstitusi tertulis adalah Inggris, Selandia Baru, dan Israel. Inggris disebut sebagai negara 'tanpa konstitusi' dalam arti Inggris tidak seperti negara pada umumnya yang memiliki konstitusi tertulis dalam suatu dokumen yang disebut Konsitusi (Efendi, 2017: 1).Konstitusi Inggris karakteristiknya sebagai produk yang berkelanjutan selama berabad-abad, sebagian besar bertahap, dan hasil evolusi damai(Barnett, 2002: 3).

Konstitusi Indonesia adalah

Undang-Undang Dasar Negara Republik Indonesia Tahun 1945 yang untuk seterusnya disebut UUDNRI Tahun 1945. UUDNRI Tahun 1945 sebagaimana konstitusi-konstitusi negara lain pada umumnya memuat tentang organisasi negara, hak-hak asasi manusia, prosedur mengubah undang-undang dasar, dan terkadang larangan untuk mengubah sifat tertentu dari undang-undang dasar (Budiardjo, 1996: 101). Konstitusi memiliki pelbagai fungsi satu di antaranya adalah sebagai instrumen untuk memberikan hak-hak bagi warga negara terhadap negara (Webley and Samuels, 2012:53). Fungsi ini dapat dilihat dari dua sudut pandang. Dari persepektif warga negara maka hak-hak warga negara adalah sesuatu yang akan dterima oleh warga negara dari negara sedangkan dari sisi negara merupakan kewajiban hukum yang harus dilakukan kepada warga negara.

UUDNRI Tahun 1945 mengatur hak-hak warga negara Indonesia pada Bab XA tentang Hak Asasi Manusia terdiri atas 10 pasal dimulai Pasal 28A sampai dengan Pasal 28J. Di luar Bab XA itu, hakhak warga negara Indonesia juga diatur pada pasal-pasal lain, misalnya Pasal 27 ayat (3) yang mengatur hak atas pekerjaan dan penghidupan yang layak. Salah satu hak asasi manusia bagi warga negara yang dijamin oleh UUDNRI Tahun 1945 adalah hak sebagaimana diatur pada Pasal 28E yaitu hak untuk memilih pendidikan. Hak ini kemudian dipertegas lagi oleh Pasal 31 ayat (1) yang dimuat pada Bab XIII tentang Pendidikan dan Kebudayaan yang menetapkan bahwa setiap warga negara berhak mendapat pendidikan.

Hak asasi manusia atas pendidikan ini menjadi milik semua warga negara Indonesia tanpa melihat suku, agama, ras, golongan, strata sosial maupun ekonomi, kondisi fisik maupun mental, dan lainnya.Salah satu kelompok yang harus terpenuhi haknya untuk mendapatkan pendidikan adalah anak 
berkebutuhan khusus. Anak berkebutuhan khusus adalah anak yang memiliki keterbatasan seperti kesulitan membaca, kesulitan mendengar, berjalan, atau melihat. Jika disimpulkan adalah anak yang mendapatkan suatu program pendidikan secara khusus termasuk anak yang memiliki IQ Superior (Gifted) (Hunt, Nancy, 2003:1). Negara bertanggung jawab atas penyediaan kesempatan serta sarana dan prasarana pendidikan bagi anak berkebutuhan khusus ini. Oleh karena kewajiban ini adalah kewajiban hukum maka kegagalan pelaksanaannya berimplikasi pada tanggung jawab hukum.

Berdasarkan paparan di atas, masalah sentral dalam tulisan ini: Bagaimanakah tanggung jawab negara atas hak pendidikan bagi anak berkebutuhan khusus. Masalah sentral itu kemudian dibagi menjadi dua sub masalah, yaitu: bagimanakah pengaturan hukum hak atas pendidikan bagi anak berkebutuhan khusus dan apakah negara dapat dipertanggungjawabkan secara hukum atas kegagalan memenuhi hak pendidikan bagi anak berkebutuhan khusus.

\section{KERANGKA TEORI}

\section{Teori Tanggung Jawab Negara}

Dalam konteks hukum, tanggung jawab lahir karena adanya pelanggaran kepentingan subyek hukum oleh subyek hukum lainnya (Verheyen, 2005:227). Konsep inti dari tanggung jawab adalah bahwa seseorang dapat menanyakan mengapa orang lain melakukan itu? Dan orang yang melakukan perbuatan itu wajib memberikan jawaban. Kegagalan dari melaksanakan tanggung jawab menyebabkan seseorang dapat dikenakan hukuman (Bexell, 2005:66).

Menurut Kelsen, tanggung jawab pada dasarnya terkait, namun tidak identik dengan konsep kewajiban hukum. Individu secara hukum diwajibkan beperilaku dengan cara tertentu, jika ia berperilaku berlawanan dengan cara tertentu itu menjadi syarat dikenakannya tindakan paksa. Individu yang dibebani sanksi dikatakan 'bertanggung jawab' atas pelanggarannya (Kelsen, 2005: 119). Tanggung jawab berada di antara perbuatan salah dan memberikan ganti kerugian atas perbuatan salah itu (Garner, 2004:392).

Subyek hukum yang kepentingannya dapat dilanggar maupun menjadi pelanggar yang kemudian dapat dibebani tanggung jawab itu baik perorangan atau individu maupun badan-badan hukum privat seperti perusahaanperusahaan perseroan dan lainnya maupun badan hukum publik seperti negara. Pada saat ini tidak berlaku prinsip imunitas negara sebagaimana prinsip yang berasal dari Rowami princeps legibus solutus yaitu konsep yang berhubungan dengan kedaulatan negara sebagai kekuasaan absolut atas rakyatnya, wilayah, dan alat-alat pemerintahan tanpa pembatasan oleh hal-hal yang 
bersifat keduniawian (Bankas, 2005:38). Prinsip kedaulatan negara membawa implikasi: negara tidak dapat melakukan kesalahan (Gores and Lee, 2007:369). Ditinggalkannya prinsip imunitas negara ini atas dasar kepentingan praktis yaitu menghindari keburukan (Bankas, 2005:38-39).

$$
\text { Tanggung jawab negara }
$$
berarti negara harus memberikan kompensasi jika terjadi kerugian secara langsung atau tidak langsung, materiil atau mental kepada warga negara (Toshiro dalam Zhang, 1999:1). Tanggung jawab negara di mana ketika warga negara mengalami kerugian yang disebabkan oleh aktivitas negara, dan di mana warga negara tidak bertanggung jawab atas kerugian diri mereka sendiri, negara dapat bertanggung jawab atas kerugian itu (Zhang dalam Zhang, 1999:49). Semua aktivitas negara dapat dipersoalkan di pengadilan, dan tidak ada aktivitas negara yang bebas dari hukum untuk memberikan ganti kerugian atas kerugian yang terjadi (Depenheur dalam Zhang, 1999:174).

Tanggung jawab negara lahir berdasarkan dua konsep dasar (Bell, 2006:4-5). Pertama, konsep kesalahan. Konsep ini berdasarkan kewajiban moral bagi siapa saja untuk melakukan perbaikan terhadap kerugian yang disebabkan oleh kesalahannya. Secara alamiah, adanya kerugian melahirkan kewajiban moral bagi pelakunya untuk melakukan tindakan perbaikan.
Kedua, konsep risiko. Konsep ini berhubungan dengan seseorang yang tanpa kesalahan menciptakan suatu keadaan yang melahirkan suatu risiko terjadinya bahaya dan tidak ada dasar untuk melahirkan tanggung jawab atas risiko itu. Tiadanya unsur kesalahan tidak dengan sendirinya menghilangkan tanggung jawab atas risiko itu. Berdasarkan terminologi ekonomi berlaku prinsip: kita harus menginternalisasikan biaya atas perbuatan kita sendiri bukan kepada perbuatan orang lain.

\section{Teori Hak}

Hak adalah persoalan pokok dalam filsafat. Bagi sebagian ahli hukum esensi dari hukum adalah menemukan kejelasan, interpretasi dan perlindungan hak.Hukum dipandang sebagai "ilmunya hak" yang melihatkan pencarian keutuhan teori mengenai sifat dan arti hak dalam sistem hukum (Curzon, 1995: 235).Hak tidak hanya menjadi topik pembahasan oleh hukum tetapi telah menjadi diskusi dan kajian lintas displin yaitu oleh ilmu politik, filsafat, dan antroplogi. Ilmu-ilmu itu membicarakan mengenai pondasi/dasar, arti, dan fungsi hak dalam konteks yang berbeda (Sastry, 2011:12).

Hak lebih sekadar dari norma-norma, harapan atau ukuran berperilaku. Hak adalah aturan yang ditetapkan batas-batasnya mengenai apa yang harus diterima oleh pemegang hak dari siapa pihak yang harus menghormati dan melaksanakan hak dari pemegang 
hak. Hak tidak hanya dapat diharapkan tetapi dapat dituntut dan dipaksakan pelaksanaannya (Curzon, 1995: 235). Hak ada yang memaknainya sebagai kewenangan yang diberikan oleh hukum untuk mewujudkan kepentingankepentingan tertentu. Hak ditafsirkan sebagai suatu kewenangan untuk mengubah suatu keadaan, melaksanakan kewenangan yang diakui oleh hukum, dan dianggap sebagai akibat yang lahir terkait kepentingan pemilik hak (Curzon, 1995: 236).

$\begin{gathered}\text { Pemegang hak memiliki } \\ \text { empat keistimewaan }\end{gathered}$
(Curzon,
2001:291). Pertama, claim. Hal ini berarti bahwa setiap orang memiliki kewajiban hukum untuk memperbolehkan pemegang hak melakukan beberapa tindakan, dan pemegang hak dapat melakukan tuntutan untuk melaksanakan hak melakukan beberapa tindakan tersebut. Kedua, privilege. Artinya pemegang hak memiliki kebebasan untuk melakukan tindakan atau menahan diri untuk melakukan beberapa tindakan dan orang lain tidak dapat menuntut si pemegang hak untuk melakukan atau tidak melakukan sesuatu yang menjadi privilegenya. Ketiga, power yang berarti pemegang hak memiliki kebebasan untuk melakukan beberapa tindakan yang dapat mengubah hak dan kewajiban si pemegang hak itu sendiri. Keempat atau terakhir, immunity yang merujuk pada hubungan hukum pemegang hak dengan orang lain dan orang lain di luar hubungan hukum itu tidak memiliki kemampuan untuk mempengaruhi hubungan hukum itu.

\section{PEMBAHASAN}

\section{Pengaturan Hukum Hak atas Pendidikan Bagi Anak Berkebutuhan Khusus}

\section{Pengaturan}

Pengaturan adalah langkah pertama untuk jaminan atas hak pendidikan bagi anak berkebutuhan khusus. Hak diatur dalam aturan hukum yang memiliki kekuatan hukum mengikat untuk dilaksanakan. Bagi pemilik hak, ia dapat segera menunjuk di mana haknya itu ia peroleh sementara bagi pihak yang harus melaksanakan hak itu terikat kewajiban hukum untuk melaksanakannya.

Dasar utama hak untuk mendapatkan pendidikan bagi anak berkebutuhan khusus adalah Pasal 31 UUDNRI Tahun 1945 yang dengan eksplisit telah menetapkan hak bagi setiap warga negara Indonesia tanpa terkecuali untuk mendapatkan pendidikan. Jadi, hak atas pendidikan adalah hak konstitusional atau hak yang diatur dalam konstitusi.Hak konstitusional untuk memperoleh pendidikan ini masih bersifat umum (memang demikian materi muatan konstitusi) sehingga harus diatur penjabarannya lanjut dalam peraturan perundang-undangan di bawah konstitusi baik itu undangundang maupun peraturan pelaksanaannya. Pasal 28I ayat (5) 
UUDNRI Tahun 1945 pun menetapkan: Untuk menegakkan dan melindungi hak asasi manusia sesuai dengan prinsip negara hukum yang demokratis, maka pelaksanaan hak asasimanusia dijamin, diatur, dan dituangkan dalam peraturan perundangundangan.

Hak atas pendidikan bagi anak berkebutuhan khusus diatur dalam Pasal 54 Undang-Undang No. 39 Tahun 1999 tentang Hak Asasi Manusia yang menetapkan sebagai berikut:

Setiap anak yang cacat fisik dan atau mental berhak memperoleh perawatan, pendidikan, pelatihan. dan bantuan khusus atas biaya negara untuk menjamin kehidupannya sesuai dengan martabat kemanusiaan, meningkatkan diri, dan kemampuan berpartisipasi dalam kehidupan bermasyarakat dan bernegara.

Hak atas pendidikan bagi anak berkebutuhan khusus juga diatur dalam Undang-Undang No. 23 Tahun 2003 tentang Sistem Pendidikan Nasional Nasional pada Pasal 5 ayat (2) sebagai berikut:

Warga negara yang memiliki kelainan fisik, emosional, mental, intelektual, dan/atau sosial berhak memperoleh pendidikan khusus.

Undang-Undang No. 19 Tahun 2011 tentang Pengesahan Convention on the Rights of Persons with Disabilities (Konvensi Mengenai Hak-Hak Penyandang
Cacat) mengatur hak atas pendidikan bagi anak berkebutuhan khusus sebagai berikut:

Article 24

\section{Education}

1. States parties recognize the right of persons with disabilities to education. With a view to realizing this right without discrimination and on the basis of equal opportunity.

Undang-Undang No. 35 Tahun 2014 tentang Perubahan Atas Undang-Undang No. 23 Tahun 2002 tentang Perlindungan Anak mengatur hak pendidikan bagi anak berkebutuhan khusus pada Pasal 9 ayat (2) sebagai berikut:

Selain mendapatkan Hak Anak sebagaimana dimaksud pada ayat (1) dan ayat (1a), Anak Penyandang Disabilitas berhak memperoleh pendidikan luar biasa dan anak yang memiliki keunggulan berhak mendapatkan pendidikan khusus.

Undang-Undang No. 8 Tahun 2016 tentang Penyandang Cacat mengatur hak atas pendidikan bagi anak berkebutuhan khusus dalam Pasal 5 ayat (1) huruf e yang menetapkan bahwa penyandang cacat memiliki hak atas pendidikan. Hak untuk mendapatkan pendidikan ini dirinci dalam Pasal 10 yang 
menetapkan hak pendidikan untuk penyandang disabilitas meliputi hak:

a. Mendapatkan pendidikan yang bermutu pada satuan pendidikan di semua jenis, jalur, dan jenjang pendidikan secara inklusif dan khusus;

b. Mempunyai kesamaan kesempatan untuk menjadi pendidik atau tenaga kependidikan pada satuan pendidikan di semua jenis, jalur, dan jenjang pendidikan;

c. Mempunyai kesamaan kesempatan sebagai penyelenggara pendidikan yang bermutu pada satuan pendidikan di semua jenis, dan jenjang pendidikan; dan

d. Mendapatkan akomodasi yang layak sebagai peserta didik.

Konvensi Hak-Hak Anak yang telah diratifikasi Pemerintah Indonesia dengan Keputusan Presiden No. 36 Tahun 1990 tentang Pengesahan Convention on the Rights of the Child (Konvensi tentang Hak-Hak Anak) mengakui hak pendidikan bagi anak berkebutuhan khusus sebagai berikut:

\section{Pasal 23}

3. Mengakui kebutuhankebutuhan khusus anak cacat...untuk menjamin bahwa anak-anak cacat

mempunyai akses yang
efektif ke dan untuk
menerima pendidikan,
pelatihan, pelayanan
kesehatan, pelayanan
rehabilitasi, persiapan
untuk bekerja, dan
kesempatan
rekreasi...

\section{Pelaksanaan}

Hak atas pendidikan bagi anak berkebutuhan khusus yang telah diatur dalam konstitusi dan peraturan perundang-undangan di bawahnya hanya memiliki nilai jika ditindaklanjuti dengan tindakan pelaksanaannya. Tanpa tindakan pelaksanaan maka hak-hak itu hanya menjadi hak di atas kertas. Ada tetapi sama dengan tidak ada.

Peraturan perundangundangan fungsinya hanya sampai pada memuat hak, kewajiban, dan sanksi tetapi pelaksanaannya di lapangan sangat bergantung pada aparatur pelaksana peraturan perundang-undangan. Di sini peran pelaksana peraturan perundangundangan sangat penting. Sebagus apapun peraturan perundangundangan dibuat hanya akan menjadi rangkaian kata-kata tanpa guna jika tidak didukung dan dilaksanakan oleh aparatur yang berkompeten dan berintegritas.

Keberadaan aparatur yang berkompeten dan berintegritas saja belum cukup harus dilengkapi dengan sarana dan prasarana yang memadai. Sarana dan prasarana itu dapat berupa tenaga pendidik, 
kurikulum, gedung sekolah dan lainlainnya. Sarana dan prasarana ini pun dapat digerakkan hanya jika ada sumber dana yang cukup, misalnya untuk gaji guru, pembelian alat-alat sekolah, atau menyewa/membangun gedung.

\section{Tanggung Jawab Negara atas Kegagalan Memenuhi Hak atas Pendidkan Bagi Anak Berkebutuhan Khusus}

\section{Kewajiban Hukum}

Hak berhadapan dengan kewajiban. Hak adalah keuntungan, manfaat bagi yang menikmatinya, kewajiban sebaliknya, tugas, menuntut, berat bagi yang harus memenuhinya. Hak dan kewajiban meskipun berbeda dan bertolak belakang dalam sifatnya, mereka sama dalam sumbernya dan tidak dapat dipisahkan dalam keberadaan mereka. Hukum tidak dapat memberikan manfaat bagi seseorang tanpa memberikan beban pada orang lain pada saat yang sama, atau dengan kata lain tidak mungkin memberikan hak pada seseorang, kecuali dengan menciptakan kewajiban yang terkait dengan hak itu yang dibebankan atas orang lain (Bentham, MDCCCLXIY:93).

Kewajiban adalah keharusan secara hukum atau moral untuk melakukan atau tidak melakukan sesuatu (Garner, 2004: 1104). Kewajiban adalah keharusan untuk melakukan tindakan (Salmond, 1913:180). Subyek hukum yang dibebani kewajiban tertutup pintu untuk menetapkan pilihan lain selain harus melaksanakan atau tidak melaksanakan tindakan yang menjadi kewajibannya.

Kewajiban dapat dibedakan antara kewajiban hukum dengan kewajiban moral atau alamiah. Kewajiban hukum adalah tindakan yang berhubungan dengan kesalahan hukum sementara kewajiban moral terkait dengan kesalahan moral. Suatu tindakan yang diakui sebagai kewajiban oleh hukum, pelaksanaannya dapat diserahkan kepada pengadilan yang diselenggarakan negara. Ketika hukum mengakui suatu tindakan tertentu sebagai kewajiban, maka pelaksanaannya dapat dipaksakan dan pengabaiannya dapat dikenakan hukuman. Suatu kewajiban adalah kewajiban hukum karena hukum menentukannya demikian, tidak harus karena kewajiban itu pelaksanaannya dapat dipaksakan secara hukum atau karena dapat dijatuhi sanksi (Salmond, 1913:180).

Kewajiban negara untuk memenuhi hak atas pendidikan bagi anak usia dini adalah kewajiban hukum yang dibebankan oleh konstitusi dan peraturan perundangundangan di bawahnya dan bukan kewajiban moral. Pasal 28I ayat (4) UUDNRI Tahun 1945 menetapkan bahwa perlindungan, pemajuan, penegakan, dan pemenuhan hak asasi manusia adalah tanggung jawab negara, terutama pemerintah. Kewajiban ini dituangkan kembali dalam pelbagai undang-undang terkait hak pendidikan bagi anak 
berkebutuhan khusus, salah satu contoh adalah Undang-Undang No. 39 Tahun 1999 tentang Hak Asasi Manusia. Pasal 71 dari undangundang tersebut menetapkan: Pemerintah wajib dan bertanggung jawab menghormati, melindungi, menegakan, dan memajukan hak asasi manusia yang diatur dalam Undang-undang ini, peraturan perundang-undangan lain, dan hukum internasional tentang hak asasi manusia yang diterima oleh negara Republik Indonesia.

Penetapan kewajiban negara atas hak pendidikan bagi anak berkebutuhan khusus sebagai kewajiban hukum memiliki implikasi sebagai berikut:

1. Negara terikat harus melaksanakan kewajibannya itu;

2. Pelaksanaan atas kewajiban itu dapat dipaksakan melalui lembaga pengadilan;

3. Pengabaian atas kewajiban itu dapat dikenakan sanksi hukum.

\section{Ganti Kerugian}

Ganti kerugian melekat pada hak, di mana ada hak di situ ada ganti kerugian. Hal ini sesuai prinsip hukum ubi ius ibi remedium yang berarti di mana ada hak, maka di situ juga ada ganti kerugian (Samuel, 2000:215). Berdasarkan prinsip hukum ubi ius ibi remediumsetiap pelanggaran hak hukum memberikan hak bagi korban untuk mendapatkan ganti kerugian yang seimbang
(Daniel, 2008:506). Prinsip ibi ius ibi remedium pada intinya mengandung beberapa implikasi hukum (Efendi, 2016:254). Pertama, setiap orang yang haknya dilanggar berhak untuk mendapatkan ganti kerugian. Kedua, nilai ganti kerugian harus seimbang dengan kerugiannya. Ketiga, siapa saja yang melanggar hak orang lain dapat dituntut untuk membayar ganti kerugian.

Ganti kerugian sebagai buah kegagalan melaksanakan kewajiban hukum dapat terjadi atas dasar kesepakatan pihak pelanggar dengan pihak terlanggar atau melalui keterlibatan pihak ketiga.Menurut cara pertama pihak pelanggar sepakat memberikan ganti kerugian kepada pihak yang haknya dilanggar tanpa melalui campur tangan pihak ketiga. Pihak pelanggar menyadari dan mengakui telah mengabaikan kewajiban hukumnya yang berakibat pada kerugian pihak lain dan secara sukarela ia bersedia memperbaiki kerugian tersebut. Sementara itu untuk cara yang kedua pelanggar dapat tidak mengakui telah melanggar kewajiban hukumnya atau mengakui melakukan pelanggaran tetapi menolak memberikan ganti kerugian sesuai nilai yang diminta oleh pihak yang haknya dilanggar atau menolak sama sekali untuk membayar ganti kerugian. Pihak yang haknya terlanggar tidak puas kemudian menuntut ganti kerugian melalui forum yang dibentuknya bersama pihak pelanggar (mediasi, arbitrase, dan lainnya) atau melalui pengadilan negara. Khusus di 
pengadilan, pihak yang haknya dirugikan harus dapat membuktikan bahwa kerugiannya memang disebabkan oleh perbuatan pihak yang diduga melanggar haknya sehingga pengadilan akan memutuskan bahwa pihak tersebut diwajibkan untuk membayar ganti kerugian. Putusan pengadilan ini dapat dipaksakan pelaksanaannya jika pihak yang diputuskan membayar ganti kerugian tidak dengan sukarela memenuhi kewajibannya.

Ganti kerugian itu sendiri berarti pembayaran sejumlah uang untuk suatu kerugian atau perintah kepada pelanggar untuk melakukan sesuatu atau menahannya melakukan sesuatu (Efendi, 2016:261). Ganti kerugian tujuannya untuk menempatkan pihak yang haknya dilanggar pada posisi semula sebelum terjadi perbuatan pelanggaran (Stuhmcke, 2001:140).

\section{KESIMPULAN}

Tanggung jawab negara atas hak pendidikan bagi anak berkebutuhan khusus lahir dari penetapan oleh hukum bahwa kewajiban negara adalah memenuhi hak pendidikan bagi anak berkebutuhan khusus. Kewajiban hukum negara itu berhadapan dengan hak hukum anak berkebutuhan khusus untuk menerima pendidikan. Bagi anak berkebutuhan khusus sebagai pemegang hak maka ia tidak hanya dapat berharap agar haknya dipenuhi tetapi dapat menuntut secara hukum supaya haknya diberikan. Bagi negara kegagalan melaksanakan kewajiban hukumnya itu dapat menyebabkan dijatuhinya beban untuk membayar ganti kerugian.

\section{DAFTAR PUSTAKA}

Altman, Andrew. TT. Arguing about Law: An Introduction to Legal Philosophy. Belmont: Wadsworth Publishing Company.

Bankas, Ernest K. 2005. The State Immunity Controversery in International Law: Private Suits against Sovereign States in Domestic Court. BerlinHeidelberg: Springer.

Barnett, Hilaire. 2002. Constitutional \& Administrative Law, Fourth Edition. London.Sydney: Cavendish Publishing Limited.

Bell, John. 2006. Governmental Liability: Some Comparative Reflections.

Barcelona:InDret.

Bentham, Jeremy. MDCCCLXIY. Theory of Legislation, Translated From the French of Etienne Dumont by $\mathrm{R}$. Hildreth. London: Trubner \& Co.

Bexell, Magdalena. 2005. Exploring Responsibility Public and Private in Human Rights Protection Duties and State Responsibility. Sweden: Department of Political Science Lund University. 
Budiardjo, Miriam. Dasar-Dasar

Ilmu Politik. Jakarta:

Gramedia Pustaka Utama.

Curzon, L.B. 1995. Jurisprudence, 2nd Edition. London and Sydney:

Cavendish

Publishing Limited. 2001. $Q$ \& A Series

Jurispridence, Third Edition.

London. Sidney: Cavendish

Publishing Limited.

Daniel, Scott R. 2008. "The Spy Who Sued The King: Scaling for the Fortress of Executive Immunity for the Constitutional Torts in Wilson v. Libby. " Journal of Gender, Social Policy \& The Law. Vol. 16:4.

Depenheur, O. "Governmenal Liability in Germany." Dalam Yong Zang, Comparative Studies on Government Liability in East and Southeast Asia. The Haque, London and Boston: Kluwer Law International.

Efendi, A'an. 2016. Hukum Penyelesaian Sengketa Lingkungan di Peradilan

Tata Usaha Negara. Jakarta: Sinar Grafika.

2017. Laporan

Constitutional and

Administrative Law Making

Procedures Course. London:

London Corporate Training.

Fuke, Toshiro. 1999. "Historical Phases of State Liability as Law of Remedies-Some Introductory Remarks." Dalam Yong Zang,
Comparative Studies on

Government Liability in East and Southeast Asia. The Haque, London and Boston: Kluwer Law International.

Hunt, Nancy. 2005. Exceptional Childen and Youth. USA: Houghton Mifflin Company

Garner, Bryan (ed). 2004. Black's Law Dictionary, Eight Edition. St. Paul: Thomson Business West.

Gores, Matthew and HP Lee. 2007. Australian Administrative Law: $\quad$ Fundamentals, Principles and Doctrine. Cambridge: Cambridge University Press.

Kelsen, Hans. 1949. General Theory of Law and State, Translated by Anders Wedberg. Cambridge, Massachusetts: Harvard University Press. . 2005. Pure Theory of Law, Translation from the Second (Revised and Enlarged) German Edition by Max Knight, Clark, New Jersey: The Lawbook Exchange, Ltd. . 1992. Inttroduction to the Problems of Legal Theory, A Translation of the First Edition of the Reine Rechtslehre of Pure Theory of Law translated by Bonnie Litschewki Paulson and Stanley L. Pauson. Oxford, Clarendon Press.

Majelis Permusyawaratan Rakyat Republik Indonesia. 2011. Undang-Undang

Dasar 
Negara Republik Indonesia

Tahun 1945. Jakarta:

Sekretariat Jenderal MPR RI.

Salmond, John W. 1913.

Juriprudence, Fourth Edition.

London: Stevens and Haynes.

Samuel, Geoffry. 2000. Sourcebok on Obligations and Legal Remedies, Second Edition. London and Sidney: Cavendish Publishing Limited.

Sastry, S.N. 2011. Introduction to Human Rights and Duties, First Edition. Pune: University of Pune.

Stuhmcke, Anita. 2001. Essential Tort Law, Second Edition. Sidney and London: Cavendish Publishing Pty Limited.

Turpin, Colin and Adam Tomkins. 2007. British Government and the Constitution Text and Materials, Sixth Edition. Crambridge: Cambridge University Press.

Verheyen, Roda. Climate Change Damage and International Law Prevention Duties and State Responsibility. Leiden and Boston: Martinus Nijhoff Publishers.

Webley, Lisa and Harriet Samuels. 2012. Public Law: Text, Cases, and Materials, Second Edition. Oxford: Oxford University Press.

Zhang, Y. 1999. "Governmental Liability in China." Dalam Yong Zang, Comparative Studies on Government Liability in East and Southeast Asia. The Haque, London and Boston: Kluwer Law International. 